\title{
Determinants of Small and Medium Enterprises Performance in Nigeria: The Role of Government Support Policy
}

\author{
Maryam Imam Ibrahim ${ }^{1}$, Bintu Mustapha ${ }^{2}$ \\ ${ }^{1}$ Department of Business Administration, Ramat Polytechnic Maiduguri, Maiduguri, Nigeria \\ ${ }^{2}$ Department of Marketing, University of Maiduguri, Maiduguri, Nigeria
}

Email address:

botulbe@gmail.com (M. I. Imam), bintumustapha65@gmail.com (B. Mustapha)

\section{To cite this article:}

Maryam Imam Ibrahim, Bintu Mustapha. Determinants of Small and Medium Enterprises Performance in Nigeria: The Role of Government Support Policy. International Journal of Business and Economics Research. Vol. 8, No. 2, 2019, pp. 41-49.

doi: $10.11648 /$ j.ijber.20190802.11

Received: January 20, 2019; Accepted: March 20, 2019; Published: April 29, 2019

\begin{abstract}
Small and medium enterprises (SMEs) play a significant social and economic role in both developed and developing nations. Despite the relevance and important of SMEs, the literature indicates there are very few studies that attempted to investigate the factors that influence the performance of SMEs in Nigeria, particularly the relationship between entrepreneurial orientation (EO), contemporary marketing (CM) and government support policyand the performance of small and medium enterprises (SMEs). The study used structured questionnaires; data was collected from 240 SMEs in northeast Nigeria. The findings of the study indicate a significant positive relationship between EO and CM on the Performance of SMEs. In addition, the results of the study validate that government support policy moderates the relationship between EO and CM on the performance of SMEs in Nigeria. The study implications for policy makers, government, regulators and SMEs owner-managers is to look at government support policy as it affects SMEs performance by providing conducive environment for business operation.
\end{abstract}

Keywords: Entrepreneurial Orientation, Contemporary Marketing, Government Support, Performance, Nigeria

\section{Introduction}

Entrepreneurship can be described as a process of 'creative destruction that introduces new goods or new quality of goods, introduction of new methods of production, opening of a new market, utilization of new sources of supply and carrying out new organizational forms [2]. This definition considers entrepreneurship as the creation of new economic activity, any activity that brings changes to the market is considered as entrepreneurship [49]. According to this definition, business growth is also viewed as entrepreneurship because advancement brings some changes to the peripheral environment as well as to the internal environment. Furthermore, [28] make emphasizes that growth is attained through entrepreneurship and argued that, growth means entrepreneurship because small businesses grow gradually. Recent management studies have mostly focused on the Entrepreneurial Orientation (EO) that explains how entrepreneurship is put into practice. Entrepreneurialorientation in an organization has been acknowledged as an important feature of organizational culture that stimulates organizational value creation. EO is considered as a breeding ground for the growth and development of small and medium enterprises (SMEs) [34].

SMEs play significant and important roles towards the development of a nation's economy [25]. The SME sector is a major engine which encourages the growth of nations' economy, wealth creation and employment generation [5341]. In Nigeria, SMEs in manufacturing, agriculture, services, and other sectors, has been considered as the engine drive and has contributed substantially to the economy [36-45]. Although, Nigerian government depends on petroleum product for internal revenue generation, sustainable growth and increase in SME performance and competitiveness especially, in the manufacturing sector will open numerous doors for employment opportunities, tangible and intangible 
assets (investment) in the environment [23]. In spite of the exploitation of petroleum products and numerous challenges faced by SMEs, the sector has developed rapidly in the areas of business venture and job creation over the years [45]. According to available statistics, SMEs provide gainful employment for about $90 \%$ of the Nigerian population [38]. Available reports also suggest that most of the operators in the manufacturing sector are SMEs engaged in processing, production and delivery of goods [37]. Consequently, to achieve optimal economic development and to reduce dependency on crude oil for redistribution of economic wealth, the government of Nigeria seeks rescue from the SME sector by employing economic diversification [40-51].

On the other hand, the overbearing springs of evolving competitive advantage has unswervingly plagued the way SMEs are managed [19]. The market and environment transformations, the growth of competition and ambiguity in all business practises, the gravity to integrate new technologies into day-to-day business operations, the internationalization and interconnectivity of markets have all contributed significantly to a landscape modification of large, medium and small businesses [24-22]. Statistics show that three out of every five SMEs die before their $5^{\text {th }}$ anniversary and eight out of ten potential entrepreneurs are discouraged from establishing their dream venture every year in Nigeria [22]. This insubstantiality of SMEs, essentially at start-up, explains why they require support.

\section{Literature Review and Hypotheses}

SMEs performance is globally linked to the growth and development of a nation's economy [32]. This expounds the significance of this segment as an instrument that can create not only economic growth in emerging nations but also advanced countries [47]. Furthermore, SMEs have been acknowledged globally as one of the major contributing sector to GDP in the areas of employment generation, poverty reduction, rapid industrialisation, encourage the spread of technology and innovation and wealth creation among citizens [27]. SMEs in Nigeria are perceived to have provided important economic advantages in the areas of employment and empowerment of the citizenry, proving about $90 \%$ of job opportunities [11-37].

\subsection{Entrepreneurial Orientation and SMEs Performance}

Alegre and Chivareiterates that the features of an entrepreneurial firm "is the one that engages in product market innovation, undertakes somewhat risky ventures, and a pioneer in a "proactive' 'innovations, always ahead of its competitors" [2]. The EO dimensions affects business performance in a different way, for instance, a level of high innovation shows a greater positive relationship with sales growth, while pro-activeness is positively related to sales level, sales growth and return on investment [29-35]. On the other hand, risk-taking produced an inverted "U shaped" curvilinear relationship with sales growth [33]. In some instances, pro-activeness and competitive aggressiveness are contrarily correlated to performance in different circumstances [12, 31, 32]. The potential role of EO as a vector of performance has been evaluated both empirically and theoretically. Empirically, a number of studies have found an inconsistentrelationship between EO and performance [1]. Theoretically, it was emphasized that EO has been confirmed as a factor having a positive bearing on business performance through the creation of a competitive advantage that transmutes into substantial financial success [52]. In view of the findings from previous researches, this study posited the following hypothesis:

H1: There is a significant relationship between EO and performance of small and medium enterprises

\subsection{Contemporary Marketing and SMEs Performance}

Contemporary marketing (CM), the assessment of "a multiparadigm philosophy and a multi-procedure approach" [4], has marked a step forward in the research of marketing standards, often stalled by the growth of transactional versus relational marketing debates. $\mathrm{CM}$ covers both Business to Business (B2B) and Business to Customer (B2C) domains and is descriptive of the marketing conduct of every business, independent of its nature, scope, lifespan stage or core business [50]. The CM practices was first examined by [5] in 1997 looking at transaction, database, interaction, and network marketing. In addition to this four practices, e-marketing as the fifth aspect of CM practice was introduced by Coviello et al., [8]. In this context, Coviello et al., examine both marketing practice and the association between practice and performance of SMEs in tourism accommodation sector [9]. The findings from their study showed that, in all the practices examined, only interaction marketing and transaction marketing positively affect performance.

However, despite increase attention in the literature on newer forms of practice such as database marketing, emarketing, and network marketing, and the fact that they are all implemented by the firms in [7] sample, these forms of marketing appear to have no impact in terms of either directly influencing performance or enhancing the effect of transaction marketing and interaction marketing. Additionally, the implementation of e-marketing increases the effectiveness and efficiency of database marketing and network marketing practices. The success of e-marketing therefore comes from the support and enhancement of existing marketing practices, rather than e-marketing transforming the business model. Thus, the adoption of emarketing is shown to largely be a consequence of its integration with other practices. In view of the findings from previous researches, the following hypothesis is proposed:

H2. There is a significant relationship between contemporary marketing and Performance of small and medium enterprise

\subsection{Government Support Policy and SMEs Performance}

Government support policies on SMEs are strategies or 
programs employed by government and their regulatory agencies to influence and determine decisions making process that foster economic growth by ensuring that the environment is adequately protected for business operations [51-40] highlighted that Nigerian economy is faced by serious challenges due to negligence in SMEs sector for over four decades. Hence, the problem is a matter of grave concern to the Nigerian government and other stakeholders and needs an affirmative action to overcome the challenges [51]. As a result of the negligence and government commitment to diversify more on SMEs, the President of Nigeria recently during his speech delivered at the 2016 Economic Summit Retreat in Abuja, Nigeria, reiterate more incentives to SMEs so as to prove themselves capable of manufacturing quality products good enough for export [46].

In the same vein, Federal government of Nigeria announced the reduction of taxes for SMEs to thrive and promote inclusive economic growth [51]. Furthermore, the Nigerian government through the Nigerian Customs Services banned the importation of goods that can be sourced and produced in Nigeria. This policy aims at encouraging the indigenous SMEs to strengthen their market potentials which will subsequently improve their productivity and performance [39]. Consequently, the government of Nigeria resolves to engage more with SMEs and entrepreneurial activities towards ensuring viable economic development and wealth creation by supporting the sector [40]. In view of the current government's commitment therefore, this study examines the moderating effect of government support to strengthen the relationship between EO and CM on SMEs performance in Nigeria hence, postulated the following hypothesis.

H3: Government support acts as a moderating variable between EO and performance of small and medium enterprises

H4: Government support acts as a moderating variable between CM and performance of small and mediumenterprises.

Based on the discussion and results on EO, CMand firm performance, the studyconceptualizesthe model as shown in Figure 1. In Figure 1, EO and CM are the independent variables, SMEs performance is the dependent variable while government support is the moderating variable.

\subsection{Underpinning Theory}

A resource-based view of a firm explains its ability to deliver sustainable competitive advantage when resources are managed, such that their outcomes cannot be imitated by competitors, which ultimately creates a competitive barrier [21]. RBV explains that a firm's sustainable competitive advantage is reached by virtue of unique resources being valuable, rare, inimitable, non-tradable, and non-substitutable (VRIN), as well as firm-specific resource capabilities [14-3]. Penrose ascertained that organizations normally own resources which provides them with competitive advantage and holds the key to superior long-term performance [42]. The resources that are scarce, specialized and difficult to trade, imitate, or appropriate are viewed as intangible [43]. Therefore, this study applied the resource-based view (RBV) as underpinning theory. The theory turn out to be one of the most widely used theoretical frameworks to underline the way companies utilize their resources to achieve performance.

\section{Methodology}

In this section, the researchers discussed the data collection procedure and the method applied in the data analysis. Data for this exercise was composed through the use of survey method where s structured questionnaire was employed. The unit of analysis was the SMEs spread across northeast region of Nigeria represented by their ownermanagers. Zahra and Covin, asserted that in a study related to SMEs, usually the owner-managers are the target respondents given that they have more knowledge regarding theircompanies' strategies and overall business situations [55]. This is in conformity with previous studies [31].

The sample in this study was selected by using stratified random sampling were the population embraces a number of distinct categories. The sample was then organized by these categories into separate strata and each stratum was sampled as an independent sub-population, out of which individual elements wererandomly selected. Similarly, measurements used in the questionnaire were adapted from previous studied and modified to suit Nigerian context. The items on EO were adapted from [10], CM items adapted from [5], government support items adapted from [44] while SME performance items adapted from [48] all in 7 point-likert scale. According to [36] and [37] annual report, about 8,662 registered SMEs were available in the northeast Nigeria which is the target population of this study. The sample size for the study based on Dillman'sformula [13] is 368 and out of this, only two hundred and fifty-six (256) questionnaires were returned, 240 usable questionnaires went for final analysis, yielding a $65 \%$ response rate. SPSS 22v and PLS-SEM 2.0 were used in the analysis.

\section{Statistical Analysis and Findings}

An initial test of validity and reliability using smart PLS 2.0 was conducted. The model as depicted in figure 1 has two independent variables namely entrepreneurial orientation and contemporary marketing which represent a firm valuable, rare, inimitable and non-substitutable (VRIN) resources and capabilities as signified by the RBV theory. The dependent variable is firm performance (SME) and government support is the moderating variable. 


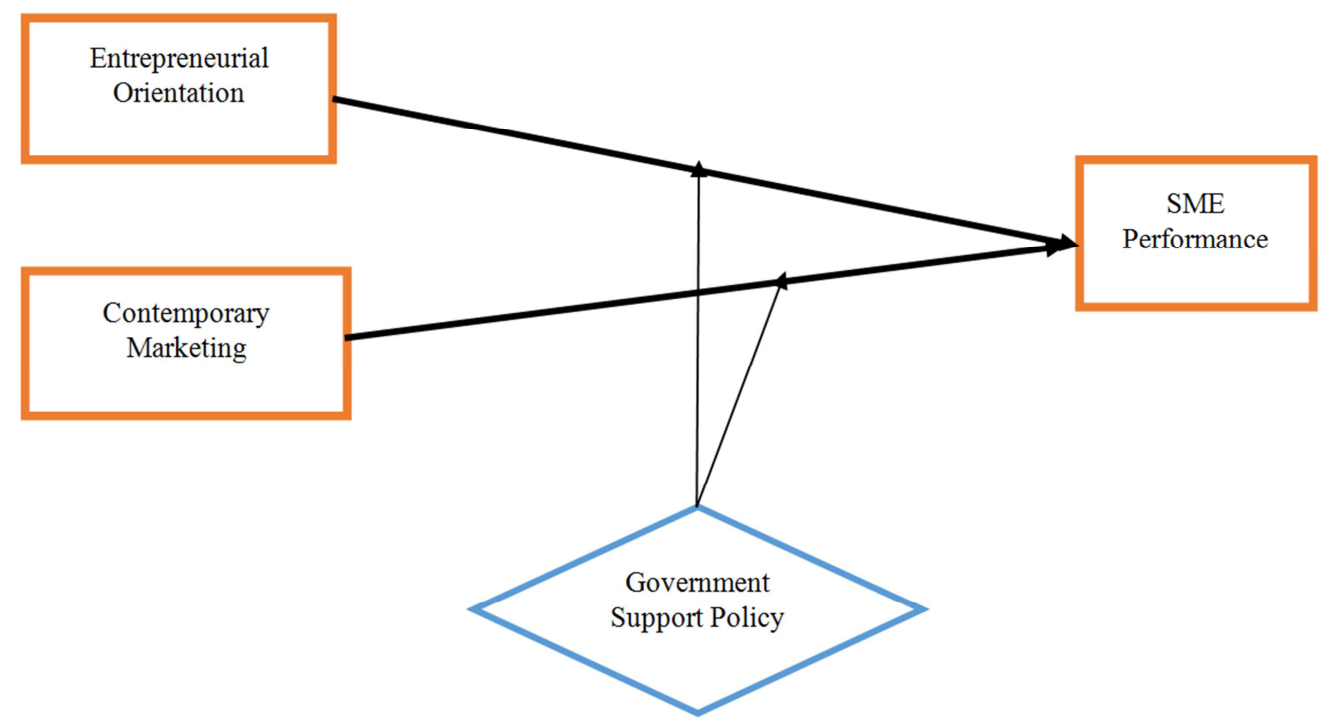

Figure 1. Conceptual framework of the Study.

To assess the measurement model for the study, constructs validity and reliability of specific items measuring each latent construct, construct reliabilitydiscriminate validity, as well as convergent validity for each of reflective constructs (SME performance and government support) were evaluated in order to determine the accurateness of the measurement [17].

After calculating PLS algorithm, the next action was toassessthe indicators reliability to see if there is any item indicator with loading less than 0.4 so as to delete them from the model. Hence all the items indicators met the requirement as presented in table 1; there is no case for deletion.

Table 1. Factor Loadings, CR and AVE.

\begin{tabular}{lllcl}
\hline Constructs & Items & Loadings & Composite Reliability & AVE \\
\hline \multirow{4}{*}{ Government } & GSP1 & 0.89 & 0.97 & 0.70 \\
& GSP10 & 0.90 & & \\
& GSP11 & 0.82 & & \\
& GSP12 & 0.84 & & \\
& GSP13 & 0.87 & & \\
& GSP2 & 0.84 & & \\
& GSP3 & 0.79 & & \\
& GSP4 & 0.84 & & \\
& GSP5 & 0.86 & & \\
& GSP6 & 0.84 & & \\
SME Performance & GSP7 & 0.81 & & \\
& GSP8 & 0.78 & & \\
& GSP9 & 0.82 & & \\
& PER1 & 0.88 & & \\
& PER10 & 0.89 & & \\
& PER2 & 0.91 & & \\
& PER3 & 0.90 & & \\
& PER4 & 0.89 & & \\
& PER5 & 0.90 & & \\
& PER6 & 0.79 & & \\
& PER7 & 0.83 & & \\
& PER8 & 0.91 & & \\
& PER9 & 0.90 & & \\
\hline
\end{tabular}

Table 2. Discriminate validity.

\begin{tabular}{lll}
\hline Constructs & GSP & SME PER \\
\hline GSP & 0.84 & \\
SME PER & 0.45 & 0.88 \\
\hline
\end{tabular}

Similarly, to ascertain the formative construct (EO and $\mathrm{CM})$, the researchers have examined two conditions upon each indicator to determine whether they aresignificant in the construct or not. First was to assess the collinearity among the indicators using variance inflation factor (VIF) values, the threshold of which is 5 . The second condition is to assess the significance of the statistical contribution of each formative indicator to the main construct.

Table 3. Assessment of collinearity and significance level of formative constructs.

\begin{tabular}{llllll}
\hline \multicolumn{2}{l}{ Constructs } & VIF & Outer Loadings & Outer Weight & T-statistics \\
\hline EO & AUT & 4.04 & 0.91 & 0.9 & 1.82 \\
& CA & 3.23 & 0.93 & 0.36 & 3.57 \\
& INNO & 4.82 & 0.96 & 0.5 & 3.48 \\
& PRA & 3.75 & 0.93 & 0.26 & 2.18 \\
& RT & 4.88 & 0.85 & 0.17 & 1.87 \\
CM & DM & 4.85 & 0.88 & 0.07 & 0.79 \\
& EM & 3.92 & 0.91 & 0.13 & 1.94 \\
& IM & 4.85 & 0.93 & 0.29 & 3.61 \\
& NM & 4.91 & 0.95 & 0.3 & 2.37 \\
& TM & 3.56 & 0.98 & 0.63 & 6.19 \\
\hline
\end{tabular}

Additionally, as recommended by [15], the composite reliability and cronbach alpha for internal consistency reliability of the whole construct meet the condition ranging from 0.7 and 0.8 respectively. Equally, the average variance extracted (AVE) for convergent validity of all the constructs are considered accepted as all the AVE meet the minimum threshold of 0.5 as recommended by [18]. In conclusion, to justify the discriminant validity the square root of AVE is compared to correlation square of the interrelated variables of concern constructs which indicates adequate discriminate validity.

\subsection{Structural Model}

After satisfying all the requirements for the measurement model, this section presents the structural model of the analysis through the standard bootstrapping method using 
5000 bootstrap sample for 240 dataset to ascertain the significance levels for the direct and the moderating relationships [16-18]. These include the hypotheses testing, evaluation of R-square, effect size and predictive relevance.

Table 4. Direct relationship hypotheses.

\begin{tabular}{lllll}
\hline Hypotheses & Beta & Std Error & T Statistics & Decision \\
\hline CM $->$ SME PER & 0.3915 & 0.0503 & 7.7859 & Supported \\
EO - SME PER & 0.1822 & 0.0513 & 3.5501 & Supported \\
\hline
\end{tabular}

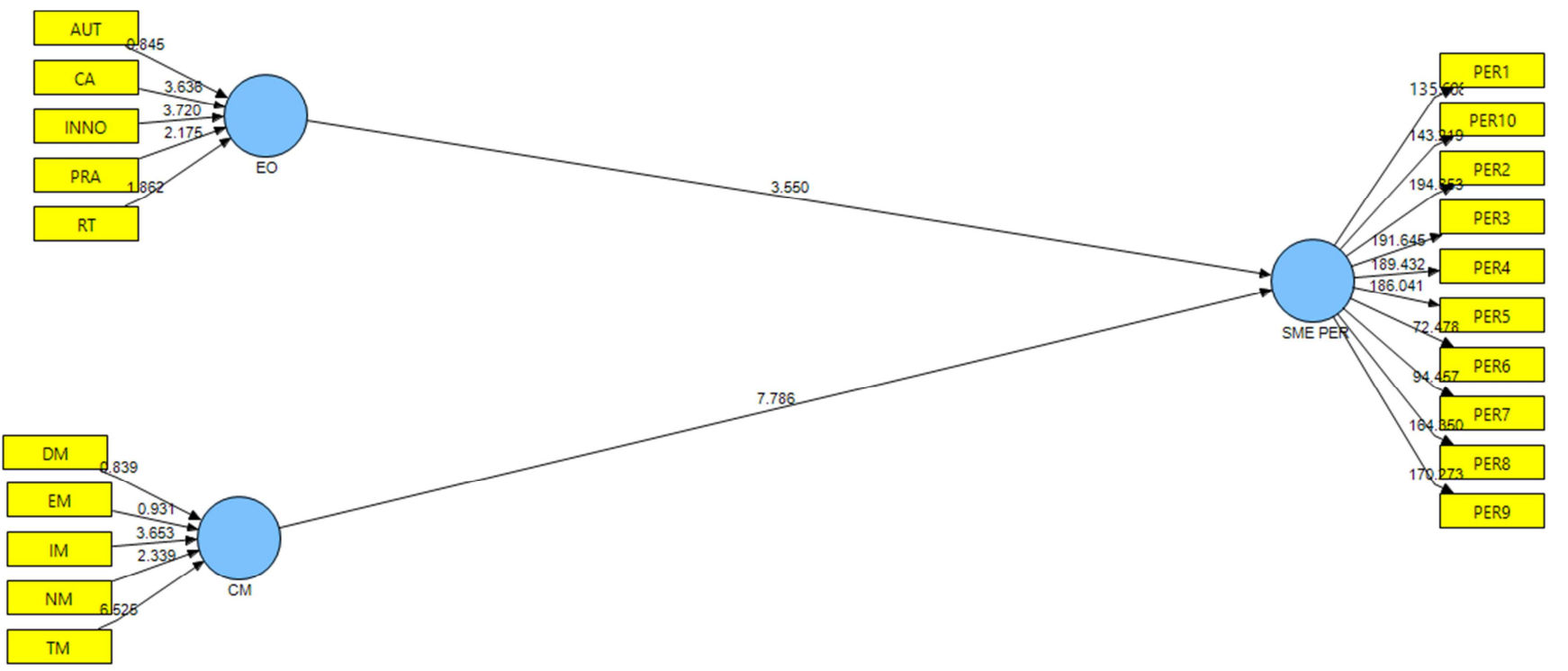

Figure 2. Measurement Model.

\subsection{Testing Moderating effect}

This study employed a product indicator approach using PLS SEM to evaluate the strength of the moderating effect of government support policy on the relationship between Entrepreneurial orientation and Contemporary marketing on
SMEs performance. Equally, as presented in table 5, government support policies is significantly related and moderates the relationships between both contemporary marketing (CM) and SMEs performance as well as entrepreneurial orientation(EO) and SMEs performance.

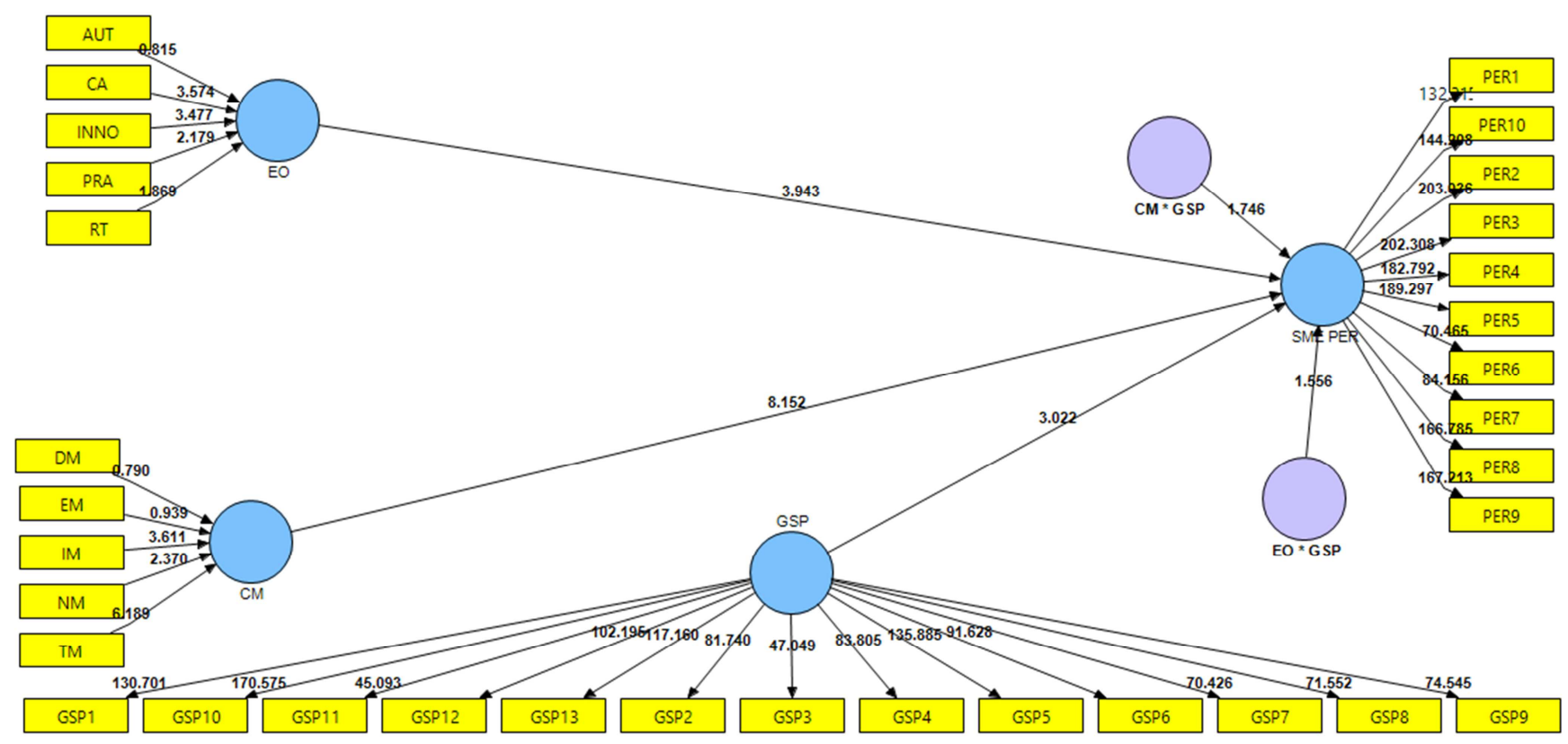

Figure 3. Moderating effect.

Table 5. Moderation hypotheses.

\begin{tabular}{lllll}
\hline Hypotheses & Beta & Standard Error & T Statistics & Decision \\
\hline CM * GSP -> SME PER & 0.0982 & 0.0562 & 1.7456 & Supported \\
EO * GSP - SME PER & -0.0957 & 0.0615 & 1.5562 & Supported \\
\hline
\end{tabular}


Table 6. R-square.

\begin{tabular}{ll}
\hline Constructs & R Square \\
\hline SME PER & 0.31 \\
\hline
\end{tabular}

Table 7. Determination of Effect size.

\begin{tabular}{lllll}
\hline Moderation & Included & Excluded & f-squared & Effect size \\
\hline R-squared & 0.312 & 0.311 & 0.001 & None \\
\hline
\end{tabular}

Consequently, it can be predicted that government support policy moderates the relationship between CM and SMEs and Performance at 5\% significance level using 1-tail.
Statistically the moderating effect is significant, hence hypothesis supported. Similarly, EO was moderated using $10 \%$ significance level and the result shows government support policy moderating the relationship between EO and SMEs Performance thus, the hypothesis was supported.

Table 8. Predictive relevance.

\begin{tabular}{llll}
\hline Total & SSO & SSE & 1-SSE/SSO \\
\hline SME PER & 2400 & 1822.771 & 0.2405 \\
\hline
\end{tabular}

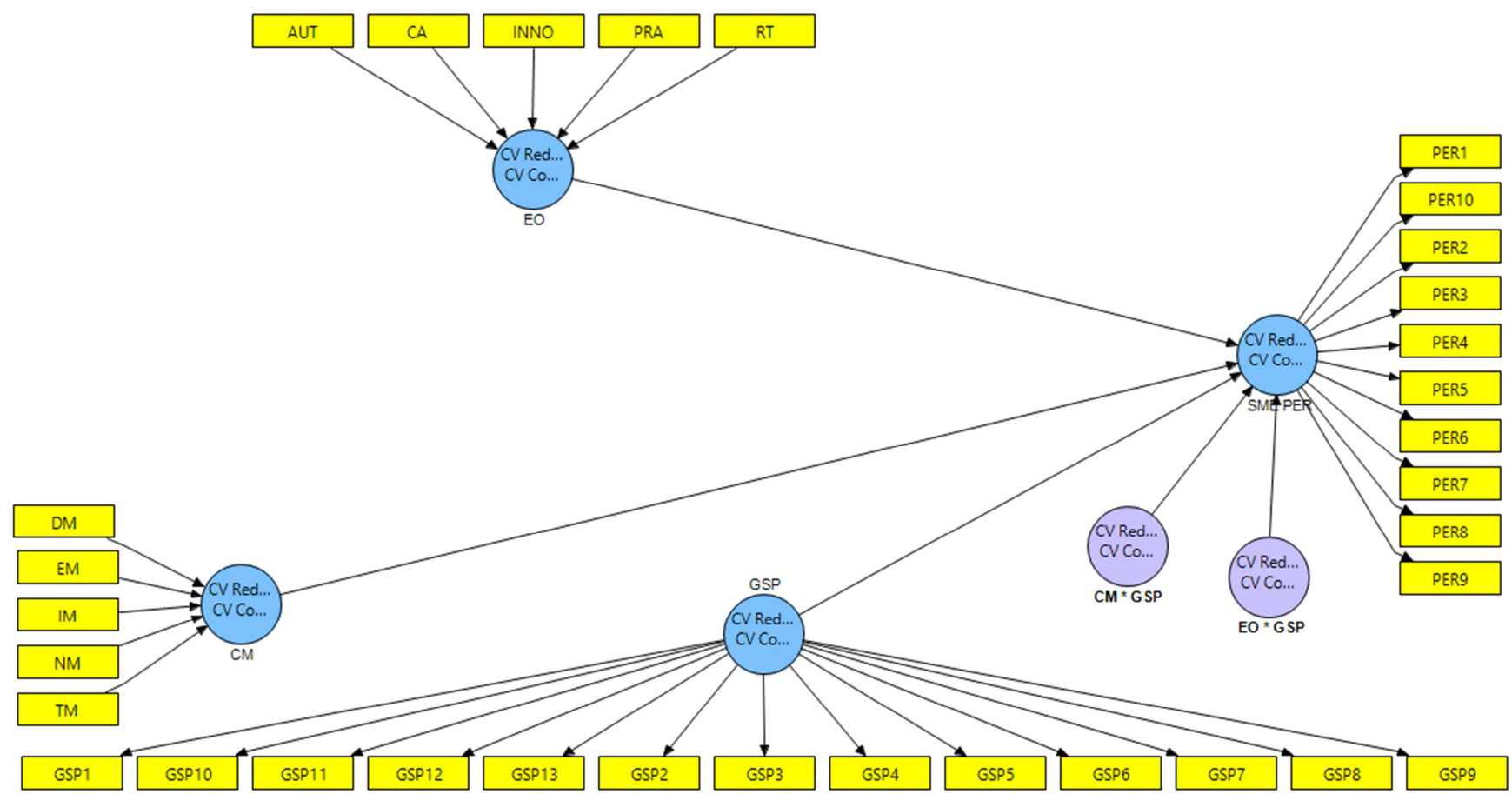

Figure 4. Predictive Relevance.

\subsection{Evaluation of Predictive Relevance, Effect Size, and R-Square}

The essence of assessing the predictive relevance in PLSSEM is to precisely predict the data points of indicators in reflective measurement model of endogenous construct and endagenous single-item construct [18]. $\mathrm{A} \mathrm{Q}^{2}$ values greater than zero for a certain reflective endagenous laten variable signifiesthe path model's predictive relevance for a specific constructs [18-20].

Based on this contention, the predictive relevance for this study found to be 0.2405 which is above the threshold. Similarly, [6] provided criteria for judging predictive relevance as; $0.02,0.15$ and 0.35 aresmall, medium and large respectively. Therefore, in line with these arguments, thecurrent research model has a medium predictive relevance.

\section{Discussions}

The objective of this study ismainly to examine the relationships between entrepreneurial orientation (EO) and contemporary marketing (CM) on the performance of SMEs in Nigeria and to determine the extent to which government support can strengthen the relationship for a greater performance of SMEs. The statistical findings of the study revealed that all the four hypotheses were supported, the hypothesis on direct relationship between the independent variable and the dependent variable, contemporary marketingand performance is positively significant $(\beta=$ $0.3915, \mathrm{SE}=0.0503, \mathrm{TS}=7.7859 .2935)$, this result is consistent with previous results (see [5 and 26]) which are all positively significant. Similarly, entrepreneurial orientation and performance is positively significant $(\beta=0.1822, \mathrm{SE}=$ 0.0513 , TS $=2.35501$ ), this also confirmed with prior studies $[30,35]$, they found entrepreneurial orientation as positively related to performance. Therefore, contemporary marketingand entrepreneurial orientation practices of SMEs have significant influence on performance. Additionally, hypotheses three and four supported the argument that government support policy moderates the relationship between contemporary marketingand performance as well as entrepreneurial orientation and performance. Therefore, CM 
$*$ GSP->PER is significant at $(\beta=0.0982, \mathrm{SE}=0.0562, \mathrm{TS}=$ $1.7456)$, while, $\mathrm{EO}^{*} \mathrm{GSP}->\mathrm{PER}$ is significant at $(\beta=0.0957$, $\mathrm{SE}=0.0615)$. Equally, the $\mathrm{R}^{2}$ included is 0.321 as well as $\mathrm{R}^{2}$ excluded is 0.311 for the two independent variable (EO and $\mathrm{CM}$ ), thus, contributed $32 \%$ to the model. Likewise, $\mathrm{f}^{2}$ value is 0.001 which predicts noneaffect size for the constructs. However, an effect size above zero shows an effect. The choice of the government support preferences for dealing with performance of SMEs needs to be vested on good diagnostic and an extensive view of the policy options.

This study would meaningfully add towards extending the borderline of existing knowledge as well as provide empirical support for practitioners. It is expected to provide more understanding on the relationship between EO, CM and SMEs performance in Nigeria. Specifically, the study would offer clarity on the moderating effects of government support policy on the relationship between the independent variables and the dependent variable so as to shed more light on the role of the policies and incentives of the Nigerian government to improve survival, growth and performance of SMEs. Similarly, the findings of this work will be of value, practically, to SME owner-managers in understanding the vital aspects of EO and CM to increase in order to improve upon their firm performance and which one to avoid. Additionally, the findings of this study are expected to enhance the knowledge and perception of SME ownermanagers and practitioners in the area of modern marketing applications to improve on existing product and new product development. The SME owner-managers and practitioners will understand that in this era of globalization equipped with improved technology, especially in the areas of IT, highly competitive and dynamic business environment, the only way to survive and remain successful and also have competitive advantage over competitors is to be entrepreneurially inclined, strategically positioned and market oriented.

\section{Conclusion}

Contemporary marketing and entrepreneurial orientation practices of SMEs have significant influence on SMEs performance. The results of the study suggest that SMEs that focus on EO and CM and use them among its key business strategies in creating sustainable competitive advantages are more likely to perform better. Additionally, results of the study validate that government support policy act as a moderator to strengthen the relationship between entrepreneurial orientation and contemporary marketing on the performance of SMEs in Nigeria. These findings are in accord with the RVB theory that emphasizes the use of internal resources and development capabilities within the firm as a source of competitive advantage. RVB views EO, $\mathrm{CM}$ and incentives from government as capabilities and resources of the firm that can influence performance, hence, indicates that the strong role of the constructs on firm growth as found in the previous studies also applies in the context of the SMEs in an emerging country like Nigeria. The conclusion drawn from the results of this study should consider thelimitation of regional bias, as the sample consists 8,626 SMEs in northeast Nigeriafrom which the sample is drawn, which may not necessarily represent the entire population. Furthermore, there is a number of baffling but vital factors that should be integrated to ascertain the causal relationship among variables and their relative explanatory power. Directions for further studies should consider the SMEs characteristics for further exploration; this may provide meaningful perspectives for understanding how individual similarities and differences affect the performance of SMEs. Secondly, the limitations of a cross-sectional research method may be overcome if a longitudinal approach isapplied in collecting data to describe the changes and the directions and extent of underlying relationships between variables. Thirdly, future studiescouldempirically examine other strategic orientations to see how they influence the performance of SMEs in order to re-validate the model.

\section{References}

[1] Al-Dhaafri, H.., Al-Swidi, A.., \& Yusoff, R. Z.. (2016). The mediating role of total quality management between the entrepreneurial orientation and the organizational performancermation. The TQM Journa, 28(1), 89-111. http://doi.org/DOI 10.1108/TQM-03-2014-0033

[2] Alegre, J., \& Chiva, R. (2013). Linking Entrepreneurial Orientation and Firm Performance: The Role of Organizational Learning Capability and Innovation Performance. Journal of Small Business Management, 51(4), 491-507. http://doi.org/10.1111/jsbm.12005

[3] Barney, J. B. (1986). Strategic Factor Market: Expectations, Luck and Business Strategy. Journal of Management Sciences., 32(10), 1231-1241.

[4] Brodie, R. J., Coviello, N. E., \& Winklhofer, H. (2008). Contemporary Marketing Practices research program : a review of the first decade. Journal of Business \& Industrial Marketing, 23(2), 84-94. http://doi.org/10.1108/08858620810850191

[5] Brodie, R., Winklhofer, H., Coviello, N. E., \& Johnston, W. J. (2007). Is E-marketing Coming of Age? An Examination of the Penetration of E-marketing and Firm Performance. Journal of Interactive Marketing, 21(1), 1-21. http://doi.org/0.1002/dir.20071

[6] Chin, W. W. (1998). The Partial Least Squares Approach to Structural Equation Modeling: Modern Metod for Business Research ( $3^{\text {rd }}$ Ed.). New Jersey: Lawrence Erlbaum Association, Publishers.

[7] Coviello, N. E., \& Joseph, R. M. (2012). Creating Major Innovations with Customers: Insights from Small and Young Technology Firms. Journal of Marketing, 76, 87-104.

[8] Coviello, N., Milley, R., \& Marcolin, B. (2001). Understanding IT-Enabled Interactivity in Contemporary Marketing. Journal of Interactive Marketing, 15(4), 18-33.

[9] Coviello, N., Winklhofer, H., \& Hamilton, K. (2006). Marketing Practices and Performance of Small Service Firms: An Examination in the Tourism Accommodation Sector. Journal of Service Research, 9(1), 38-58. http://doi.org/10.1177/1094670506289533 
[10] Covin, J. G., \& Wales, W. J. (2011). The Measurement of Entrepreneurial Orientation. Entrepreneurship Theory and Practice, 1-6.

[11] Dauda, Y. A., \& Akinbade, W. A. (2010). Employee's Market Orientation and Business Performance in Nigeria : Analysis of Small Business Enterprises in Lagos State. International Journal of Marketing Studies, 2(2), 134-143.

[12] Dess, G. G., Lumpkin, G. T., \& Covin, J. G. (1997). Entrepreneurial Strategy Making and Firm Performance: Tests of Con. Strategic Management Journal, 18(6), 677-695. http://doi.org/10.1002/(SICI)1097-0266(199710)18:9<677.

[13] Dillman, D. A. (2007). Mail and Internet Survey: The tailored Design Method (Second Edi). New York: John Wiley \& Sons, Inc.

[14] Finney, R. Z., Lueg, J.., \& Campbell, N.. (2008). Market Pioneers, Late Movers and the Resource-Based View (RBV): A Concptual Model. Journal of Business Research, 61(9), 925-932.

[15] Hair, J. F., Ringle, C. M., \& Sarstedt, M. (2011). PLS-SEM: Indeed a Silver Bullet. Journal of Marketing Theory and Practice, 19(2), 139-153.

[16] Hair, J. F., Sarstedt, M., Pieper, T. M., \& Ringle, C. M. (2012). The use of partial least squares structural equation Modeling in strategic management research: a review of past practices and recommendations for future application. Long Range Planning, 45(5/6), 320-340.

[17] Hair jr, j. F., Hult, G. T. M., Ringle, C. M., \& Sarstedt, M. (2014). A Primer on Partial Least Squares Structural Equation Modeling (PLS-SEM (5th ed.). USA: SAGA Publication Incorporated.

[18] Hair, J. F., Sarstedt, M., Hopkin, L., \& Kuppelwieser, V. G. (2014). Partial least squares structural equation Modeling (PLS-SEM): An emergin tool in business research review, 26(2), 106-121.

[19] Hapenciuc, C. V., Pinzaru, F., Vatamanescu, E.-M., \& Stanciu, P. (2015). Converging sustainable entrepreneurship and the contemporary marketing practices. An insight into Romanian start-ups. Amfiteatru Economic, 17(40), 938-954. Retrieved from http://www.researchgate.net/publication/280565770

[20] Hernández-Perlines, F., Moreno-García, J., \& Yañez-Araque, B. (2016). The mediating role of competitive strategy in international entrepreneurial orientation. Journal of Business Research. http://doi.org/10.1016/j.jbusres.2016.04.142

[21] Hooley, G. J., Greenley, G. E., Cadogan, J. W., \& Fahy, J. (2005). The performance impact of marketing resources. Journal of Business Research, 58(1), 18-27. http://doi.org/10.1016/S0148-2963(03)00109-7

[22] Ibrahim, M. I., Keat, O. Y., \& Abdul-Rani, S. H. B. (2016). Moderating effect of government supports policy on the relationship between entrepreneurial orientation and SMEs performance in Nigeria: A framework. International Journal of Management Research \& Review, 6(12), 1716-1729.

[23] Imeokparia, P. O., \& Ediagbonya, K. (2014). Small and Medium Scale Enterprises (SMEs): A Catalyst in Promoting Economic Development in Nigeria. Journal of Education and Practice, 5(33), 92-99.

[24] Ionita, D. (2012). ENTREPRENEURIAL MARKETING : A
NEW APPROACH FOR CHALLENGING TIMES. Academy of Economic Studies, 7(1), 131-150.

[25] Iweka, H., Babajide, A., \& Olokoyo, F. O. (2016). Dynamics of Small Business in an Emerging Market: Challenges and Opportunities. In 3rd International Conference on African Development Issues (pp. 91-99).

[26] Iyalla, A. J. (2015). Contemporary Marketing Practices in Nigerian Financial Services: The 7ps, Drivers, Enablers and Inhibitors. British Journal of Marketing Studies, 3(2), 26-47.

[27] Kale, Y. (2012). The Nigeria Poverty Profile 2010 Report. In National Bureau of Statistics annual Conference. Abuja, Nigeria: National Bureau of Statistics.

[28] Kantur, D. (2016). Strategic Entrepreneurship: Mediating the Entrepreneurial Orientation-performance Link. Management Decision, 54(1), 24-43. http://doi.org/10.1108/MD-11-20140660

[29] Kreiser, P. M., \& Davis, J. (2012). Entrepreneurial Orientation and Firm Performance: The Unique Impact of Innovativeness, Proactivenessand Risk-taking. Journal of Small Business \& Entrepreneurship, 23(1), 39-51. http://doi.org/10.1080/08276331.2010.10593472

[30] Kreiser, P. M., Marino, L. D., Kuratko, D. F., \& Weaver, K. M. (2013). Disaggregating entrepreneurial orientation: the non-linear impact of innovativeness, proactiveness and risk-taking on SME performance. Journal of Small Business and Economics, 40, 273 291. http://doi.org/10.1007/s11187-012-9460-x

[31] Lechner, C., \& Gudmundsson, S. V. (2012). Entrepreneurial orientation, firm strategy and small firm performance. International Small Business Journal, 32(1), 36-60. http://doi.org/10.1177/0266242612455034

[32] Lumpkin, G. T., \& Dess, G. G. (2001). LINKING TWO DIMENSIONS OF ENTREPRENEURIAL ORIENTATION TO FIRM PERFORMANCE: THE MODERATING ROLE OF ENVIRONMENT AND INDUSTRY LIFE CYCLE. Journal of Business Venturing, 16, 429-451.

[33] Madhoushi, M., Sadati, A., \& Delavari, H. (2011). Entrepreneurial Orientation and Innovation Performance : The Mediating Role of Knowledge Management. Asian Journal of Business Management 3(4), 310-316.

[34] Maritz, A., De Waal, A., \& Verhoeven, B. (2011). Entrepreneurial and innovative marketing: a systematic review of the literature. Innovative Marketing, 7(4), 28-37.

[35] Naranjo-Valencia, J. C., Jimenez-Jimenez, D., \& Sanz-Valle, R. (2016). Studying the links between organizational culture, innovation, and performance in Spanish companies. Revista Latinoamericana de Psicologia, 48(1), 30-41. http://doi.org/10.1016/j.rlp.2015.09.009

[36] NBS, \& SMEDAN. (2010). Survey Report on Micro, Small and Medium Enterprises (MSMEs) in Nigeria. Abuja, Nigeria.

[37] NBS, \& SMEDAN. (2013). Smedan and National Bureau of Statistics Collaborative Survey: Selected Findings. Abuja, Nigeria.

[38] Okeke, M. N., Onuorah, A. N., \& Jakpa, U. G. (2016). Impact of Strategic Management on the Performance of Small and Medium Enterprises.Global Journal of Applied, Management and Social Sciences, 11(2), 57-66. 
[39] Omonobi, K., \& Bivbere, G. (2016). Customs Re-imposed Ban on Rice Importation. Retrieved May 6, 2016, from http://www.vanguardngr.com/2016/03/customs-re-imposesban-rice-importation/

[40] Osinbajo, Y. (2015). Buhari offer Concessionary Funding to SMEs. Retrieved April 24, 2015, from http://thenewsnigeria.com.ng/2015/09/buhari-to-offerconcessionary-funding-to-smes/

[41] Osotimehin, K. O., Jegede, Charles. A, Akinlabi, Babatunde. H, Olajide, O. T. (2012). An Evaluation of the Challenges and Prospects of Micro and Small Scale Enterprises Development in Nigeria. American International Journal of Contemporary Research, 2(4), 174-185.

[42] Penrose, E. T. (1959). Profit Sharing Between Producing Countries and Oil Companies in the Middle East. The Economic Journal, 69(274), 238-254.

[43] Ray, G., Barney, J. B., \& Muhanna, W. A. (2004). Capabilities, business processes, and competitive advantage: Choosing the dependent variable in empirical tests of the resource-based view. Strategic Management Journal, 25(1), 23-37. http://doi.org/10.1002/smj.366

[44] Shariff, M. N. M., Peou, C., \& Ali, J. (2010) Moderating effect of Government Policy on Entrepreneurship and growth Performance of Small-Medium Enterprises in Cambodia. International Journal of Business and Management Science $3(1), 57-72$.

[45] SMEDAN. (2012). Survey Report on Micro, Small and Medium Enterprises (MSME) in Nigeria. Abuja, Nigeria.

[46] Sotubo, J. (2016). Full Text of the President's Speech at the Opening Ceremony of National EconomicCouncil Retreat. Retrieved July 16, 2016, from http://pulse.ng/local/buhariread-full-text-of-president-s-speech-at-opening-ceremony-of, national-economic-council-retreat-id4830400.html

[47] Staniewski, M. W., Nowacki, R., \& Awruk, K. (2016). Entrepreneurship and innovativeness of small and mediumsized construction enterprises. International Entrepreneurship and Management Journal, 1-17. http://doi.org/10.1007/s11365-016-0385-8

[48] Suliyanto, (2011), Effect of entrepreneurship orientation and marketing based reward system towards marketing performance. International Journal of Business and Social Science 2(6) 168-174.

[49] Tende, S. B. a. (2014). Government initiatives toward entrepreneurship development in Nigeria. Global Journal ofBusiness Research, 8(1), 109-120.

[50] Trainor, K. J., Rapp, A., Beitelspacher, L. S., \& Schillewaert, N. (2011). Integrating information technology and marketing: An examination of the drivers and outcomes of e-Marketing capability. Industrial Marketing Management, 40(1), 162-174. http://doi.org/10.1016/j.indmarman.2010.05.001

[51] Wakili, I. (2016). Nigeria Can Survive without Oil. Retrieved June 28, 2016, from http://www.dailytrust.com.ng/news/general/nigeria-cansurvive-without-oil-osinbajo/131850.html

[52] Wiklund, J. (1999). The Sustainability of the Entrepreneurial Orientation-Performance Relationship. Entrepreneurship Theory and Practice, 24(1), 37-48.

[53] World Bank. (2013). Doing Business 2013 Smarter Regulations for Small and Medium-Size Enterprises (10TH EDITI). Washington, DC: World Bank IFC 2013. http://doi.org/10.1596/978-0-8213-9615-5

[54] Yaacob, N. M., Mahmood, R., Zin, S. M., \& Puteh, M. (2016). Factors Affecting the Performance of Small Business Start-up under Tunas Mekar Programme. In Asian Entrepreneurship Conference. Singapore: Springer Singapore.

[55] Zahra, S. a., \& Covin, J. G. (1995). Contextual influences on the corporate entrepreneurship-performance relationship: A longitudinal analysis. Journal of Business Venturing, 10(1), 43-58. http://doi.org/10.1016/0883-9026(94)00004-E 